\title{
Erratum to: Does social status within a dominance hierarchy mediate individual growth, residency and relocation?
}

\author{
Abbas Akbaripasand • Martin Krkosek • \\ P. Mark Lokman · Gerard P. Closs
}

Published online: 28 February 2015

(C) Springer-Verlag Berlin Heidelberg 2015

Erratum to: Oecologia (2014) 176:771-779

DOI 10.1007/s00442-014-3038-z

Unfortunately, one of the author names in the reference was incorrectly published in the original publication. The correct reference should read as:

Akbaripasand A, Ramezani J, Lokman PM, Closs GP (2014) Can drifting invertebrates meet the energy requirements of drift-feeding fish? A case study on Galaxias fasciatus. Freshw Sci 33(3):904-914. doi:10.1086/676957

The online version of the original article can be found under doi:10.1007/s00442-014-3038-z.

A. Akbaripasand $(\bowtie) \cdot$ P. M. Lokman · G. P. Closs

Department of Zoology, University of Otago, PO Box 56,

Dunedin 9054, New Zealand

e-mail: ab.akbary@gmail.com

M. Krkosek

Department of Ecology and Evolutionary Biology,

University of Toronto, Toronto, ON, Canada 